\title{
IMPULSE BUYING AND POST-PURCHASE REGRET: A STUDY OF SHOPPING BEHAVIOUR FOR THE PURCHASE OF GROCERY PRODUCTS
}

\author{
Dr. Abhishek Kumar \\ Associate Professor, School of Management, Campus 7 \\ KIIT University, Bhubaneswar, Odisha, India \\ Dr. Sumana Chaudhuri \\ Postdoctoral Fellow of Indian Council of Social Science Research (ICSSR), \\ School of Management, Campus 7, \\ KIIT University, Bhubaneswar, Odisha, India \\ Dr. Aparna Bhardwaj \\ Postdoctoral Fellow, Magadh University, Bodh Gaya, Bihar, India \\ Pallavi Mishra \\ Ph.D Scholar, School of Management, Campus 7 \\ KIIT University, Bhubaneswar, Odisha, India
}

\begin{abstract}
Purpose - The aim of this paper is to study the relationship between impulse buying and post-purchase regret in the context of grocery products which requires low involvement.

Design / Methodology/ Approach - Exploratory analysis using quantitative approach is employed. The sample is drawn from the individuals who visited Reliance Fresh and Big Baazar (two important retail chains in India). The instrument measures the constructs of post-purchase regret and the impulse buying. As grocery shopping differs from the other types of shopping, some particular variations are explored.

Findings - The hypothesis tested shows that there is a positive relationship between post-purchase regret and impulse purchase. It also shows that post-purchase regret changes with the change in income. As per theory, it is expected that those individuals who are more impulsive will experience greater post-purchase regret after impulse purchase than the individuals who are less impulsive.

Although the correlation coefficient between impulse buying and post-purchase regret (0.150) is significant, the magnitude is very less. The square of correlation
\end{abstract}


coefficient will be less than 0.5 which indicates a weak relationship between the two. Hence this relationship may be taken as weak superseding significant correlation.

Originality / Value - Grocery shopping will help us in understanding the causes and how the consumption behaviour of the population changes. This article shows that we cannot generalize consumer behaviour (without including the factors in that context) because decision making and the buying behaviour gets limited. This will show directions to make strategies for low involvement products. Also very few studies have shown how the post-purchase regret changes with the change in demographics (gender and income).

\section{Paper Type - Research Paper}

Key words Impulse Buying, Post-purchase Regret, Grocery, Cognitive Dissonance.

Cite this Article: Abhishek Kumar, Sumana Chaudhuri, Aparna Bhardwaj and Pallavi Mishra, Emotional Intelligence and its Impact on Team Building through Mediation of Leadership Effectiveness, International Journal of Management, 11(12), 2020, pp 614624.

http://iaeme.com/Home/issue/IJM?Volume=11\&Issue=12

\section{INTRODUCTION}

\subsection{Shopping Behaviour}

Today the customers shop not only to fulfill their physical needs but for many other reasons. They shop to pamper themselves, gratify their psychological needs, make themselves feel good, add enthusiasm to their life, shows off their persona and boosts their self esteem etc (Pooler, 2003). More shopping decisions are made in the location of the store (Underhill, 2000). The shopping mall is a meeting place for the youth and the seniors (Graham, 1988). Shopping is an avenue where people assert themselves. Customers view that shopping is a way to escape from their problems, to relieve the stress and reduce their negative mood.

A lot of academic attention has been given to the shopping related issues. Woodruffe Burton, Eccles and Elliott (2002) claim that shopping theory exists in the literature on consumer behaviour and its strands should be splitted. Customers want the shopping experience to be smooth. Shopping is how the customers perceive the buying process with respect to the availableness, capability and the cordiality of the store (Wagner, 2007). According to Wagner (2007) the customers also rate the shopping experiences based on enjoyment, worth and superiority. The time spent in going to the store is balanced with the cost of the storage and the other costs of shopping that is not related to time in order to minimize their overall costs (Umesh, Pettit \& Bozman, 1989). It has been seen that those retail outlets that are close to the residence of the customers provide the greatest shopping value for buying groceries and so the increase in the price of the gasoline favours the local retailers (Amanor - Boadu, 2009). The quality, attractiveness and security of the shopping atmosphere are important in alluring the shoppers. If the shopping environment is not safe then the shoppers will spend less time in buying that result in reduced expenses, negative word of mouth and lack of interest to go back to the store again. Hui, Bradlow and Fader (2009) verified the accepted perception that customers get more focused when they spend more time in a buying atmosphere. One procurement leads to another procurement and this is called "the shopping momentum" which customers are not aware of (Dhar, Huber \& Khan, 2007).

Shopping is an essential component of leisure and has 4 characteristics linked to leisure (Jackson, 1991) - independence (shopping as buying), shopping for leisure (the buying of goods for use in a later leisure time), shopping and leisure (when shops and leisure amenities 
are mixed in a single place) and shopping as leisure (when shopping begins to take on the feature of leisure as an experience). Grocery shopping is a mixture of shopping as leisure and independence. A buying experience can provide value to the customers by either fulfilling its proposed objectives (e.g. buying a gift for someone you love) or by providing pleasure and/or amusement (Babin, Dardin \& Griffin, 1994).

\section{LITERATURE REVIEW}

\subsection{Impulse Buying}

Iyer (1989) claimed that impulse buying is a fact of life, since more or less all customers have made an unplanned purchase at least once in their life time while shopping. It is the innermost subject matter of the tale of Adam and Eve (Ainslee, 1975) and the central point of allegory such as the "Grasshopper and the Ants". Impulse buying behaviour has been the target of theoretical debate for many years. Therefore, it is not surprising that researchers in consumer behaviour and retailing are investigating this topic for more than fifty years (Clover, 1950; West, 1951). In marketing management, this kind of behaviour is a mystery and a divergence from the usual which explains why so many diverse products are sold each year (Weinberg \& Gottwald, 1982). Marketers have understood the influence of impulse buying which is a fundamental point in many activities related to buying.

Consumption patterns that violates the rationality principles of homo oeconomicus is a persistent area of concern in many developed countries and is so a subject of research. Homo economicus purchases products after evaluating the costs and the benefits but many individuals are not rational when they buy. The buying behaviour of the consumer rarely sticks to the principles of economic theory. The customers are driven by want, mood or feeling which is natural (Etzioni, 1986). Customers buy products for various purposes (other than because these are essential) such as to alleviate an unhappy mood, to express an identity or to just have fun. This kind of non-rational buying style is known as impulse buying (Han et al., 1991).

\subsection{Post-Purchase Regret}

In a contemporary market where many brands exist the customers' get confused when deciding what to buy (Simpson, Siguaw \& Cadogan, 2008). In order to achieve the maximum level of satisfaction and satisfy their needs, the customers use their limited resources very wisely. Greater involvement by the customers is necessary in their decision making process so that they buy the best alternative (Zeelenberg \& Pieters, 2007). Even though the customers may try to justify their buying decision, they may have the doubt as to what extent their decisions are correct. The customers evaluate the goods they buy with the goods they did not buy (Loomers \& Sugden, 1982; Boles \& Messick, 1995; Shankar, Cherrier \& Canniford, 2006). Such comparisons often result in a state of grief and psychological pain known as postpurchase regret or cognitive dissonance. When the customers perceive that their buying decisions was wrong, they regret (Landman, 1987; Heitmann, Lehmann \& Herrmann, 2007) but it is not necessary that all purchases will lead to regret (Sweeney, Hausknecht \& Souter, 2000). The gap between the expected performance of a product and its actual performance against the exchange of a certain amount of money creates post-purchase regret. Often the post-purchase phase of impulse buying are related to return of goods, financial issues, frustration, dissatisfaction with the goods purchased, guilt and objections of other individuals to such purchases.

The regret is one of the negative feeling which the individual customers do experience (Tsiros \& Mittal, 2000). The term 'regret' is viewed as the intervening factor between the process of the purchase and the occurrence of the repurchase (Simonson, 1992; Taylor, 1997; 
Tsiros \& Mittal, 2000). It occurs by the comparison between choosing one option against the ones left out during the process which is being expressed as the very opposite of joy or delight (Landman \& Manis, 1992). Therefore it is the feeling of uncomfortableness by not choosing the right one for the individual at the time and the result is being compared to the imaginative situation where the individual had chosen the right one for the given situation (Tsiros \& Mittal, 2000). Typical examples would be the feelings of 'If I had collected more information about the product I would've probably purchased the better brand' or 'If I would've purchased the product a week later when the big sales promotion have started, I would purchased the product at much better price.' Tsiros and Mittal (2000) suggested that the comparison between the chosen option and unchosen one will have an effect on the customer behaviour. The customers who experienced regret will be connected with the behaviour of 'switching the brand'. The post-purchase behaviour of the customer will have an influence on the long term business activities.

The literature on consumer behaviour shows that post-purchase regret occurs with low customer satisfaction (Inman, Dyer \& Jia, 1997; Taylor \& Schneider, 1998). Low satisfaction then leads to no repurchase intention (Tsiros \& Mittal, 2000), a tendency to shift to alternative brands (Zeelenberg \& Pieters, 1999; Bui, Krishen \& Bates, 2011; Garcia \& Perez, 2011) and negative word of mouth about the brand (Garcia \& Perez, 2011). So, knowing the causes that lead the customers to regret after making a purchase is important to the marketers.

As the effect of post-purchase regret is negative for both the customer and the marketers, the marketers should know the factors that are related to the feelings of post-purchase regret on the customer and try to lessen their psychological sufferings of sorrow and pain. The marketers should also try to strengthen the position of their brands and increase the customer loyalty. If the marketers do not try to reduce the post-purchase regret of their brands then their customers will shift to their competitors. In other words, at the stage of post-purchase regret, the efforts that are needed to convert the loyal customers of their competitors to their own brands are much less (George \& Vaoyuneyong, 2010).

There is a lot of research on regret in decision making (Starmer \& Sugden, 1998) but the amount of empirical research on the extent of regret in impulse buying is few. One study found that $80 \%$ of the customers reported negative consequences (which probably includes but is not limited to regret) from their purchases (Rook, 1987), although this depends on the situation (Rook \& Fisher, 1995).

\subsection{The Relationship between Impulse Buying and Post-Purchase Regret}

After impulse buying there are two kinds of evaluations - satisfaction and regret (Gardner \& Rook, 1998; Yang, 2006). Customers evaluate impulse buying both positively and negatively (Gardner \& Rook, 1998; Yang, 2006). These feelings may differ according to the different individuals and situations. Rook (1987) indicated that majority people would feel negative (including the financial risk, guilt etc.) after they had bought impulsively. Impulse buying would result in dissatisfaction (Piron, 1991; Chen, 2005) and regret (Piron, 1991). The survey conducted by Liang (2007) showed that $62.2 \%$ of the customers were dissatisfied. The higher the level of impulse buying, the higher the level of regret and the lower the level satisfaction incurred (Lin, Chuang \& Lai, 2005). Most of the unplanned buying leads to regret and anger (Wood, 1998). Researchers (Zhang, 1998; Wu, 2008) have demonstrated that impulse buying is related to regret towards time, place and product. According to Sweeney, Hausknecht and Souter (2000), the threshold for dissonance differs from person to person and it is not necessary that all purchases would lead to cognitive dissonance. As impulse buying takes place because of the low involvement of the customer in the buying decision it leads to postpurchase regret (Hoch \& Loewentein, 1991). On the other hand, George and Yaoyuneyong 
(2010) have proved that there is an inverse relationship between impulsive buying and postpurchase regret where the impulsive buyers were less regretful compared to planned buyers. The reason is that the customers who are not used to unplanned buying feels more sorry than a customer who is accustomed to this type of behaviour.

There are two kinds of cognitive dissonance after impulse buying. The first is to compare the actual performance of the purchased product with the expected performance of the product before purchasing. Customers often overestimate the performance of the product before buying it and do not get the expected results after buying or consuming it. This will result in dissatisfaction or regret. The second is derived from comparing different products. The customers will compare the actual performance of the purchased product with the expected performance of the product which had been considered before purchasing and has been forgone. The customer's liking of the product is inconsistent during the pre-purchase and post-purchase (Hoch \& Loewenstein, 1991). They like the product before buying but dislike it after buying. The customers buy the products in a short time without assessing it in detail. This decision is against the personal best judgment. Thus the customers regret when they find that the alternative forgone (because of impulse and careless assessment) is better than the selected one after the purchase.

\section{RESEARCH OBJECTIVES}

- To find out the nature of relationship between impulse buying and post-purchase regret.

- The impact of demographics (gender and income) on post-purchase regret.

\section{DATA AND METHODOLOGY}

The respondents are the grocery shoppers (26 and above) in Bhubaneswar and Cuttack (the two major cities of Odisha). Two leading Indian supermarket chains (Big Bazaar and Reliance Fresh) gave us consent to conduct our study in its various outlets in the diverse shopping locations within Bhubaneswar and Cuttack, so that there is a fair representation of the different segments of customers. These respondents regularly purchased grocery items for their personal or family use. Those who did not buy anything were screened out. They were told to place themselves in the service setting and look back into the store so that they could answer the questions properly. In this study, 402 customers took part. The sample has a little domination of male shoppers $(52.5 \%)$ and $47.5 \%$ of the respondents were between 26 and 35 years.

In this research the validity of the questionnaire was checked by carrying out content validity which is subjective. Here the experts give their opinion on how appropriate the measurement is or whether the measuring device (questionnaire) includes all the meanings that should be included in the variable that is being measured.

\section{MEASURING INSTRUMENTS}

\section{Impulse Buying}

In this study, impulse buying was measured using 9 items adopted from Rook and Fisher (1995). Item numbers IB1 to IB9 of the questionnaire measure impulse buying. It has a reliability of 0.818 .

\section{Post-Purchase Regret}

A 4 item scale was adopted from Bui, Krishen and Bates (2011). Item numbers PPR1 to PPR4 of the questionnaire measured post-purchase regret. It has a reliability of 0.326 . 


\section{DATA ANALYSIS AND DISCUSSION}

Research Objective 1 - To find out the nature of relationship between impulse buying and post-purchase regret

H1. Impulse buying has a significant positive association with post-purchase regret.

Table 1 Pearson Correlation between Impulse Buying and Post-purchase Regret

\begin{tabular}{|c|c|c|c|}
\hline & & $\begin{array}{c}\text { Impulse } \\
\text { Buying }\end{array}$ & $\begin{array}{c}\text { Post-purchase } \\
\text { Regret }\end{array}$ \\
\hline \multirow{3}{*}{$\begin{array}{l}\text { Post-purchase } \\
\text { Regret }\end{array}$} & Pearson Correlation & 1 & $0.150 * *$ \\
\hline & Sig. (2-tailed) & & 0.003 \\
\hline & $\mathrm{N}$ & 402 & 402 \\
\hline \multirow{3}{*}{ Impulse Buying } & Pearson Correlation & $0.150 * *$ & \multirow[t]{2}{*}{1} \\
\hline & Sig. (2-tailed) & 0.003 & \\
\hline & $\mathrm{N}$ & 402 & 402 \\
\hline
\end{tabular}

\section{Source: Computed}

The results (Table 1) show that impulse buying has a positive and significant correlation with post-purchase regret $(0.150)$ at $5 \%$ level and $\mathrm{Df}=401$ indicating that an increase in impulse buying will increase post-purchase regret. Hence, the hypothesis is accepted. As per theory, it is expected that those individuals who are more impulsive will experience greater post-purchase regret after impulse purchase than the individuals who are less impulsive.

This result can be supported by the findings of Hoch and Loewentein (1991) and Piron (1991) who found a positive effect of impulse buying on post-purchase regret. The customers are in a habit of buying and they are not loyal to any brand of grocery products. They also buy the private label brands of the store because they think that these brands are the same as the manufacturer's brands. They are motivated to buy the product because of the value for money. They do not think that the price indicates quality. They consider that the manufacturer's products have a high price because the packaging is expensive and the brand is popular. The customers are very sensitive to the sales promotions and they compare the sales promotions in different stores in their locality. These confirm the incidence of postpurchase regret in consuming the products.

Although the correlation coefficient between impulse buying and post-purchase regret $(0.150)$ is significant, the magnitude is very less. The square of correlation coefficient will be less than 0.5 which indicates a weak relationship between the two. Hence this relationship may be taken as weak superseding significant correlation. An explanation for the above could be that grocery products are low cost products and the grocery shoppers are not excited and do not seek any newness, originality or freshness because grocery shopping is a continuous and recurring activity (Rohm \& Swaminathan, 2004; Smith \& Carsky, 1996). So the postpurchase regret is also very less.

Research Objective 2 - The impact of demographics (gender and income) on post-purchase regret

H2. Impulse buying will be associated more with females' post-purchase regret than males. 
Impulse Buying and Post-Purchase Regret: A Study of Shopping Behaviour for the Purchase of Grocery Products

Table 2 Independent Sample t-test on the Opinion of the Male and the Female Respondents towards Impulse Buying

\begin{tabular}{|l|c|c|c|c|c|c|c|}
\hline & Gender & N & Mean & $\begin{array}{c}\text { Std. } \\
\text { Deviation }\end{array}$ & $\begin{array}{c}\text { Std. } \\
\text { Error } \\
\text { Mean }\end{array}$ & t-test & $\begin{array}{c}\text { Sig. } \\
\text { (2- } \\
\text { tailed) }\end{array}$ \\
\hline $\begin{array}{l}\text { Post- } \\
\text { purchase } \\
\text { Regret }\end{array}$ & Male & 211 & 2.85 & 0.60 & 0.041 & \multirow{2}{*}{0.83} & $0.40^{\text {NS }}$ \\
\cline { 2 - 6 } & Female & 191 & 2.90 & 0.61 & 0.044 & 0.83 & \\
\hline
\end{tabular}

N.B: NS - Not significant at the $5 \%$ level $(P>0.05)$ for $D f=400$

Source: Computed

The results (Table 2) show that there is no difference between the male and female customers in the case of post-purchase regret. Hence, the hypothesis is rejected.

Past research suggest that have male customers have more post-purchase regret than their female counterpart after impulse buying (Saleh, 2012). Another study shows that females are more likely to exhibit post-purchase regret than males after buying impulsively (Coley \& Burgess, 2003). Even though many previous studies suggest that gender is an important explanatory factor of post-purchase regret, the above results do not support that.

H3. Impulse buying will be positively associated more with low-income consumers' postpurchase regret, than both middle income consumers and high income consumers.

Table 3 ANOVA on the Opinion of the Respondents towards Impulse Buying Due to Income Group

\begin{tabular}{|l|l|c|c|c|c|c|}
\hline \multicolumn{2}{|c|}{} & $\begin{array}{c}\text { Sum of } \\
\text { Squares }\end{array}$ & Df & $\begin{array}{c}\text { Mean } \\
\text { Square }\end{array}$ & F & Sig \\
\hline \multirow{2}{*}{$\begin{array}{l}\text { Post- } \\
\text { purchase } \\
\text { Regret }\end{array}$} & Between Income Groups & 7.66 & 4 & 1.91 & \multirow{2}{*}{5.37} & \multirow{2}{*}{$0.00^{*}$} \\
\cline { 2 - 5 } & Within Income Groups & 141.58 & 397 & 0.35 & & \\
\cline { 2 - 7 } & Total & 149.25 & 401 & & & \\
\hline
\end{tabular}

Notes: *Significant at the $5 \%$ level $(P<0.05)$

Source: Computed

The result (Table 3) indicates that different opinions from various income groups towards post-purchase regret may be obtained and therefore income has a role to play in the postpurchase regret. Thus the hypothesis is accepted.

For the case of income, the Duncan table (post hoc test) shows that the respondents having income between 60,001 - 70,000 have a similar kind of opinion and those having income above 70,000 have another kind of opinion and those having income between 30,000-60,000 have another kind of opinion.

Past research confirms that cognitive dissonance take place for the low income customers of grocery products because they are more sensitive to the sales promotions than the high income customers (Gbadamosi, 2009). The results are supported by other studies like Saleh (2012) who found that post-purchase regret takes place with customers with lower income compared to the middle and higher income.

\section{LIMITATIONS OF THE STUDY}

Certain limitations exist for this work. They are:-

- It could be possible that customers were incapable or reluctant to express their buying intentions accurately (Kollat \& Willett, 1967). 
- The study is limited to the consumers of Bhubaneswar and Cuttack. The results cannot be generalized to the customers in the other parts of the country with dissimilar economic, social and cultural circumstances.

\section{SCOPE FOR FUTURE RESEARCH}

- There is a relation between product involvement and impulse purchase. Grocery is a low involvement product. Future research can investigate high involvement products. Product categories like home furnishings, apparel, electronics and cosmetics could also be studied. Exploring the above model on specific product categories may unveil novel dimensions.

- Researchers can also study the behaviour after the consumption such as the intention to buy repeatedly, alteration in the approach towards the brand and complaining behaviour. We think that different faces of the post-purchase regret will have different impact on these after purchase consumption behaviour variables.

\section{CONCLUSION}

The manufacturers can reduce the post-purchase regret in two ways. One way is to reduce the expectations of the customers. When the manufacturers want to attract the customers to buy impulsively they should make certain that the quality of the products is good and that the product is advertised sensibly. The second way is to increase the actual performance of the product. The retailers can reduce post-purchase regret in two ways. One way is to reduce the effect of impulse buying on post-purchase regret. So the retailers should target only those segments who have a strong buying power or those who evaluate impulse buying in a positive manner (such as young people). The retailers can strengthen the confidence of the customers when they buy by saying them that this moment and this place is the best for their buying so that the customers will not regret.

The business houses should understand why the customers regret after buying because they are always trying to find out ways so that the negative experiences that are faced by the customers can be reduced. If the business houses are aware of the different types of postpurchase regret then they can help the individuals to attain a better consumption experience. For example, if the business houses know that their customers are regretting due to the alternatives that they have not selected then they can improve their product and make it more tempting to the customers over the other options (like better features, cheaper prices). Again if the business houses know that their customers are regretting due to the change in significance, then they can find out ways to add more significance to the product (like market numerous uses of the product, add more value to the product and more liberal return policies). Again, if the business houses know that their customers are regretting due to the process (under consideration and over consideration), then with the help of good customer service representatives they can help the customers in deciding and thus provide easy access to information and thus guide them along the way. In short, if the business houses know why their customers are regretting then they can put more emphasis to reduce that particular aspect of regret.

Those customers whose income is less will have to manage their expenses rationally. If they plan their expenses then they will only buy those products that they need. So customers should try to get more involved when buying. They should prepare a list of the products that they need and discuss it with their family before going to the store so that their chance of buying unplanned goods and thus post-purchase regret reduces. 
Impulse Buying and Post-Purchase Regret: A Study of Shopping Behaviour for the Purchase of Grocery Products

\section{ACKNOWLEDGEMENT}

I would like to thank Indian Council of Social Science Research (ICSSR) for their financial support for the research, authorship and publication of this article.

\section{REFERENCES}

[1] Ainslee, G. (1975). Specious Reward: A Behavioral Theory of Impulsiveness and Impulse Control. Psychological Bulletin, 82 (4), 463 - 496.

[2] Amanor-Boadu, V. (2009). In Search of a Theory of Shopping Value: The Case of Rural Consumers. Review of Agricultural Economics, 31 (3), 589-603.

[3] Babin, B. J., Darden, W. R., \& Griffin, M. (2005). Work or Fun: Measuring Hedonic and Utilitarian Shopping Value. The Journal of Consumer Research, 20(4), 644 - 656.

[4] Boles, T. L., \& Messick, D. M. (1995). A Reverse Outcome Bias: The Influence of Multiple Reference Points on the Evaluation of Outcomes and Decisions. Organizational Behavior and Human Decision Processes, 61(3), 262 - 275.

[5] Bui, M., Krishen, A., \& Bates, K. (2011). Modeling Regret Effects on Consumer Post-purchase Decisions. European Journal of Marketing, 45(7/8), 1068 - 1090.

[6] Chen, W. (2005). The Influence of Impulsive Buying Behavior on Brand Loyalty. Wuhan University (in Chinese).

[7] Clover, V.T. (1950). Relative Importance of Impulse Buying in Retail Stores. Journal of Marketing Channels, 25, 66 -70.

[8] Coley, A., \& Burgess, B. (2003). Gender Differences in Cognitive and Affective Impulsive Buying. Journal of Fashion Marketing and Management, 7(3), 282-295.

[9] Dhar, R., Huber, J., \& Khan, U. (2007). The Shopping Momentum Effect. Journal of Marketing Research, 44, 370-378.

[10] Etzioni, A. (1986). Rationality is Anti - Entropic. Journal of Economic Psychology, 7, 17 - 36.

[11] Garcia, I. S., \& Perez, R. C. (2011). Effects of Dissatisfaction in Tourist Services: The Role of Anger and Regret. Tourism Management, 32(6), 1397-1406.

[12] Gardner, M. P., \& Rook, D.W. (1998). Effects of Impulse Purchase on Consumer's Affective States. Journal of Advances in Consumer Research, 15,127-131.

[13] Gbadamosi, A. (2009). Cognitive Dissonance: The Implicit Explication in Low-income Consumer's Shopping Behavior for "Low-involvement" Grocery Products. International Journal of Retail and Distribution Management, 37(12), 1077-1095.

[14] George, B. P., \& Yaoyuneyong, G. (2010). Impulsive Buying and Cognitive Dissonance: a Study Conducted Among the Spring Break Student Shoppers. Young Customers, 11(4), 291306.

[15] Graham, E. (1988). The Call of the Mall. Wall Street Journal, 7R, 13.

[16] Han, Y.K., Morgan, G.A., Kotsiopulos, A., \& Kang-Park, J. (1991). Impulse Buying Behaviour of Apparel Purchasers. Clothing and Textile Research Journal, 9, 13 - 21.

[17] Heitmann, M., Lehmann, D. R., \& Herrmann, A. (2007). Choice Goal Attainment and Decision and Consumption Satisfaction. Journal of Marketing Research, 44(2), 234 - 250.

[18] Hoch, S. J., \& Loewentein, G. F. (1991). Time - Inconsistent Preferences and Consumer Self Control. Journal of Consumer Research, 17(4), $492-507$.

[19] Hui, S., Bradlow, E., \& Fader, P. (2009). Testing Behavioral Hypotheses Using an Integrated Model of Grocery Store Shopping Path and Purchase Behavior. Journal of Consumer Research, 36 (3), 478 - 493.

[20] Inman, J. J., Dyer, J. S., \& Jia, J. (1997). A Generalized Utility Model of Disappointment and Regret Effects on Post Choice Valuation. Marketing Science, 16(2), 97-111.

[21] Iyer, E. S. (1989). Unplanned Purchasing: Knowledge of Shopping Environment and Time Pressure. Journal of Retailing, 65(1), 40. 
[22] Jackson, E.L. (1991). Shopping and Leisure: Implications of West Edmonton Mall for Leisure and for Leisure Research. The Canadian Geographer, 35 (3), 280-287.

[23] Kollat, D. T., \& Willett, R. P. (1967). Consumer Impulse Purchasing Behaviour. Journal of Marketing Research, 4, 21-31.

[24] Landman, J. (1987). Regret: A Theoretical and Conceptual Analysis. Journal for the Theory of Social Behavior, 17(2), 135-160.

[25] Landman, J., \& Manis, J. D. (1992). What Might Have Been: Counterfactual Thought Concerning Personal Decisions. British Journal of Psychology, 83(4), 473 - 477.

[26] Liang, S. (2007). An Empirical Study on Consumer Satisfaction Based on Integrated Model of Impulse Purchase. Statistic and Decision, 13, 84 - 85 (in Chinese).

[27] Lin, C., Chuang, S., \& Lai, C. (2005). Impulse Purchase: A Model of its Antecedents and Consequences in Consumer Decision Making. Commerce \& Management Quarterly, 6(1), 4758 .

[28] Loomers, G., \& Sugden, R. (1982). Regret Theory: An Alternative Theory of Rational Choice under Uncertainty. Economic Journal, 92(368), 805 - 824.

[29] Piron, F. (1991). Defining Impulse Purchasing. Journal of Advances in Consumer Research, $18,509-514$.

[30] Pooler, J. (2003). Why We Shop. Emotional Rewards and Retail Strategies, Connecticut: Praeger.

[31] Rohm, A.J., \& Swaminathan, V. (2004). A Typology of Online Shoppers Based on Shopping Motivations. Journal of Business Research, 57, 748-757.

[32] Rook, D. (1987). The Buying Impulse. Journal of Consumer Research, 14, 189-199.

[33] Rook, D., \& Fisher, R. (1995). Normative Influences on Impulse Buying Behavior. Journal of Consumer Research, 22, 305 - 313.

[34] Saleh, M.A.H. (2012). An Investigation of the Relationship between Unplanned Buying and Post-purchase Regret. International Journal of Marketing Studies, 4 (4), 106 - 120.

[35] Shankar, A., Cherrier, H., \& Canniford, R. (2006). Consumer Empowerment: A Foucauldian Interpretation. European Journal of Marketing, 40(9), 1013 - 1030.

[36] Simonson, I. (1992). The Influence of Anticipating Regret and Responsibility on Purchase Decisions. Journal of Consumer Research, 19, $105-118$.

[37] Simpson, P. M., Siguaw, J. A., \& Cadogan, J. W. (2008). Understanding the Consumer Propensity to Observe. European Journal of Marketing, 42(1), 196 - 221.

[38] Smith, M.F., \& Carsky, M.L. (1996). Grocery Shopping Behaviour: A Comparison of Involved and Uninvolved Consumers. Journal of Retailing and Consumer Services, 3(2), 73-80.

[39] Sweeney, J. C., Hausknecht, D., \& Souter, G. N. (2000). Cognitive Dissonance after Purchase: A Multidimensional Scale. Psychology \& Marketing, 17(5), 369 - 385.

[40] Starmer, C., \& Sugden, R. (1998). Testing Alternative Explanations of Cyclical Choices. Economica, 65, 347 - 361.

[41] Taylor, K. A. (1997). A Regret Theory Approach to Assessing Customer Satisfaction. Marketing Letters, 8 (2), 172 - 189.

[42] Taylor, S. E., \& Schneider, S. K. (1998). Coping and Simulation of Events. Social Cognition, 7(2), 174-194.

[43] Tsiros, M., \& Mittal, V. (2000). Regret: A Model of its Antecedents and Consequences in Consumer Decision Making. Journal of Consumer Research, 26(4), 410-417.

[44] Umesh, U.N., Pettit, K.L., \& Bozman, C.S. (1989). Shopping Model of the Time-Sensitive Consumer. Decision Sciences, 20 (4), 715-729.

[45] Underhill, P. (2000). Why We Buy: The Science of Shopping. Simon and Schuster, New York: NY. 
Impulse Buying and Post-Purchase Regret: A Study of Shopping Behaviour for the Purchase of Grocery Products

[46] Wagner, T. (2007). Shopping Motivation Revised: A Means. International Journal of Retail \& Distribution Management, 35 (7), 569-582.

[47] Weinberg, P., \& Gottwald, W. (1982). Impulsive Consumer Buying as a Result of Emotions. Journal of Business Research, 10 (1), 43-57.

[48] West, J. C. (1951). Results of Two Years of Study into Impulsive Buying. Journal of Marketing, 15(3), $362-363$.

[49] Wood, M. (1998). Socio-Economic Status, Delay of Gratification and Impulsive Buying. Journal of Economic Psychology, 19(3), 295-320.

[50] Woodruffe-Burton, H., Eccles, S., \& Elliott, R. (2002). Towards a Theory of Shopping: A Holistic Framework. Journal of Consumer Behavior, 1 (3), 256-266.

[51] Wu, W. (2008).A Study on the Effect of Impulse Purchase on the Brand Loyalty. South China University of Technology (in Chinese).

[52] Yang, W. (2006). The Study on Customer's Impulse Buying. Journal of Marketing Research, 6, 46 - 49 (in Chinese).

[53] Zhang, C. (1998). A Study on the Effect of Customer's Impulsiveness and Normative Appraisal on Impulse Behavior. National Science Council (in Chinese).

[54] Zeelenberg, M., \& Pieters, R. (1999). Comparing Service Delivery to What Might Have Been: Behavioral Responses to Regret and Disappointment. Journal of Service Research, 2(1), 86-97.

\section{APPENDIX}

\section{Post- Purchase Regret}

\begin{tabular}{|c|c|c|c|c|c|c|}
\hline Variable & Question & $\begin{array}{l}1 \text { (Strongly } \\
\text { disagree) }\end{array}$ & $\begin{array}{c}2 \\
\text { (Disagree) }\end{array}$ & $\begin{array}{c}3 \\
\text { (Neither } \\
\text { agree nor } \\
\text { disagree) }\end{array}$ & $\begin{array}{c}4 \\
\text { (Agree) }\end{array}$ & $\begin{array}{c}5 \\
\text { (Strongly } \\
\text { Agree) }\end{array}$ \\
\hline PPR1 & $\begin{array}{l}\text { I often feel anxiety after buying goods I have not planned before } \\
\text { entering the store. }\end{array}$ & & & & & \\
\hline PPR2 & I often feel that my unplanned purchases have little benefits. & & & & & \\
\hline PPR3 & $\begin{array}{l}\text { I often try to convince myself that the goods I have bought } \\
\text { impulsively may benefit later on. }\end{array}$ & & & & & \\
\hline PPR4 & $\begin{array}{l}\text { My planned purchases make me more satisfied than unplanned } \\
\text { purchases. }\end{array}$ & & & & & \\
\hline
\end{tabular}

\section{Impulse Buying}

\begin{tabular}{|c|c|c|c|c|c|c|}
\hline Variable & Question & $\begin{array}{c}1 \text { (Strongly } \\
\text { disagree) }\end{array}$ & $\begin{array}{c}2 \\
\text { (Disagree) }\end{array}$ & $\begin{array}{c}3 \text { (Neither } \\
\text { agree nor } \\
\text { disagree) }\end{array}$ & $\begin{array}{c}4 \\
\text { (Agree) }\end{array}$ & $\begin{array}{c}5 \\
\text { (Strongly } \\
\text { Agree) } \\
\end{array}$ \\
\hline IB1 & $\begin{array}{l}\text { When I go to the store I buy a lot of goods I did not plan to buy in } \\
\text { advance. }\end{array}$ & & & & & \\
\hline IB2 & $\begin{array}{l}\text { When I see goods in the store, I buy immediately without thinking } \\
\text { if I really need or not. }\end{array}$ & & & & & \\
\hline IB3 & $\begin{array}{l}\text { When I hesitate to buy some goods inside the store, I say to myself } \\
\text { buy now and think later. }\end{array}$ & & & & & \\
\hline IB4 & Sometimes I feel that I buy some goods impulsively. & & & & & \\
\hline IB5 & Sometimes I feel a lack of interest of some goods that I bought. & & & & & \\
\hline IB6 & I often buy some goods I do not really need. & & & & & \\
\hline IB7 & I usually buy things I do not buy ordinarily. & & & & & \\
\hline IB8 & I often buy goods and wonder why I bought them. & & & & & \\
\hline IB9 & I often buy goods and do not use them at all. & & & & & \\
\hline
\end{tabular}

